\title{
NILAI-NILAI YANG PENTING TERKAIT DENGAN ETIKA
}

\author{
Handrix Chris Haryanto ${ }^{l}$, \\ Tia Rahmania \\ Program Studi Psikologi \\ Universitas Paramadina \\ J1. Gatot Subroto Kav. 97, Mampang \\ Jakarta 12790, Indonesia \\ 'e-mail: handrix.haryanto@paramadina.ac.id
}

\begin{abstract}
The present study aims to identify the important values in an ethical context and the parties which can influence the development of ethical values in undergraduate students. Subjects in the present study were undergraduate students from Universitas Paramadina with a total of 132 students. This study used a qualitative content analysis approach with an open ended questionnaire consisting of two items. Results showed that the ethical context was around $80 \%$ based on the community value through politeness (37.88\%), tolerance (32.58\%), helping (9.85\%), and based on $20 \%$ authonomy values emphasized by honesty (9.09\%), integrity (7.58\%), discipline (2.27\%), and positive thinking $(0.76 \%)$. Subject also described that those values were mostly influenced by family (51.52\%), educator (13.64\%), friends (12.12\%), student organization (9.09\%), local society (7.58\%), educational institution (3.03\%), figure $(2.27 \%)$, and communities $(0.76 \%)$. It can be concluded that the important values to the majority of the subjects in an ethical context are in a form of respect and fulfilling others'needs, and thus indicating community oriented ethics.
\end{abstract}

Keywords: ethical concept; moral values; community ethic

\begin{abstract}
Abstrak - Studi ini merupakan sebuah studi untuk mengidentifikasi mengenai nilai-nilai yang penting terkait dengan konteks etika dan pihak mana sajakah yang memiliki pengaruh dalam membentuk nilai etika tersebut pada mahasiswa. Responden dalam penelitian ini adalah mahasiswa di Universitas Paramadina dengan jumlah 132 mahasiswa. Penelitian ini menggunakan pendekatan kualitatif analisis isi dengan menggunakan kuesioner terbuka yang terdiri dari dua pertanyaan. Hasil studi menyatakan bahwa konteks etika yang mendasarkan pada nilai community sekitar $80 \%$ berupa sopan santun $(37.88 \%)$, toleransi (32.58\%), menolong (9.85\%) dan pada nilai autonomy sekitar 20\% berupa jujur (9.09\%), integritas (7.58\%), disiplin (2.27\%), berpikir positif (0.76\%). Responden juga memaparkan bahwa nilai-nilai tersebut banyak dipengaruhi oleh keluarga (51.52\%), pendidik (13.64\%), teman $(12.12 \%)$, organisasi mahasiswa $(9.09 \%)$, masyarakat sekitar $(7.58 \%)$, institusi pendidikan (3.03\%), figur (2.27\%), komunitas (0.76\%). Berdasarkan pada hasil tersebut
\end{abstract}


maka dapat disimpulkan bahwa nilai yang penting bagi responden terkait dengan konteks etika mayoritas mengarah pada bentuk penghormatan maupun pemenuhan kebutuhan orang lain yang mengindikasikan etika yang berorientasi community.

Kata Kunci: konsep etika, nilai moral etika community.

\section{PENDAHULUAN}

Kamus Besar Bahasa Indonesia (KBBI) menjelaskan etika sebagai sebuah ilmu mengenai apa yang baik dan buruk serta tentang hak dan kewajiban yang erat kaitannya dengan moral ("etika", n.d.). Sejalan dengan konsep etika yang dipaparkan dalam KBBI para ahli di antaranya yaitu Chippendale (2001), Matsumoto dan Juang (2003), Audi (dalam Ryan \& Byson, 2011), dan Preston (dalam Zegwaard \& Campbell, 2011) menjelaskan bahwa keberadaan etika memfokuskan pada perihal yang dianggap baik dan benar. Dalam pembahasan mengenai perilaku baik dan benar itu, keberadaan moral sebagai hal yang mendasar sebagai prinsip untuk berperilaku. Dengan penjelasan tersebut maka dapat disimpulkan bahwa mempelajari keberadaan etika maka fokus yang akan menjadi pembahasan di dalamnya tidak terlepas dari nilai-nilai moral yang terkait. Selain itu, melihat lebih jauh akan keberadaan etika dan moral tersebut, yang pada dasarnya menjadi sebuah penuntun individu dalam berperilaku, tidak dapat dipungkiri merupakan sebuah produk hasil dari satu budaya (Matsumoto \& Juang, 2003).

Dalam pandangan psikologi budaya, berbicara mengenai etika secara garis besar dapat digambarkan dalam tiga bentuk yaitu autonomy, community, dan divinity (Rozin dkk., dalam Triandis \& Suh, 2002; Shweder dkk., dalam Miller, 2007). Keberadaan ketiga bentuk etika ini lebih lanjut dijelaskan oleh Shweder dkk. (dalam Miller, 2007) di mana ditekankan pada keberadaan moral yang berorientasi pada satu hal terkait dengan kehidupan individu. Etika yang bersifat autonomy berorientasi pada nilai moral yang terkait dengan permasalahan kekerasan, hak, dan keadilan. Dalam konteks etika, autonomy ini sangat menitikberatkan pada konsep moral yang dikembangkan oleh Kohlberg yang menekankan pada logika dan kognitif dalam memandang permasalahan terkait dengan moral dan etika. Etika yang bersifat community berorientasi pada nilai moral yang terkait dengan respon akan pemenuhan kebutuhan orang lain. Pada bentuk etika kedua ini terdapat penekanan pada konsep moral yang dikembangkan oleh Gilligan yang berorientasi pada kepedulian serta fokus pada pendekatan kebudayaan dalam memahami konsep kepedulian itu sendiri. Etika yang bersifat divinity lebih dijelaskan sebagai konsep etika yang bersifat konvensional karena erat kaitannya dengan permasalahan spiritual maupun keagamaan. 
Keberadaan etika tersebut, jika diteliti lebih lanjut, pada realitanya sangat erat dengan pembahasan dimensi dalam budaya yang sangat popular, yaitu konteks individualisme dan kolektivisme. Seperti halnya digambarkan oleh Shweder (2000) dan Triandis dan Suh (2002) bahwa keberadaan etika yang berorientasi community merupakan hal yang sangat penting bagi masyarakat yang lebih cenderung pada budaya kolektivis dan autonomy yang erat dengan keberadaan masyarakat yang lebih cenderung pada budaya individualis. Untuk etika yang berorientasi divinity ini pada dasarnya cenderung ke arah kolektivis (Shweder, 2000), namun juga bersifat melekat pada kedua etika sebelumnya sehingga dinilai sangat penting baik pada budaya individualis maupun kolektivis (Miller, 2007). Menjadi catatan penting lain yang mengacu pada penjelasan Morelli dan Rothbaum (2007) serta Kara (2007) bahwa ketika berbicara mengenai etika yang berorientasi autonomy dan community, pembaca akan disuguhkan dengan upaya pembedaan budaya di negara Barat dan non-Barat. Dalam hal ini, budaya di negara Barat seringkali diasosiasikan dengan budaya individualisme yang berarti berorientasi pada etika autonomy dan negara non-Barat yang diasosiasikan dengan budaya kolektivisme yang berarti berorientasi pada etika community dengan lebih menekankan pada konteks harmoni, penghormatan, serta pemenuhan tugas dan tanggung jawab yang tidak dapat dilepaskan dari keberadaan individu lain.

Berdasarkan pada pembahasan yang telah digambarkan, maka pertanyaan yang dimunculkan dalam penelitian adalah bagaimana dengan kajian etika dalam konteks masyarakat Indonesia khususnya terkait dengan orientasi autonomy atau community. Upaya memperoleh pemahaman atas pertanyaan tersebut maka pendekatan psikologi indigenous menjadi dasar yang dirasa tepat dalam penelitian ini. Dalam pendekatan psikologi indigenous digambarkan dengan pendekatan yang mementingkan memahami manusia secara kontekstual (keluarga, sosial, kultural, dan ekologis) (Kim \& Berry, 1993; Kim, Yang, \& Hwang, 2010). Pemahaman secara konstekstual dimaknai dengan upaya melihat perilaku individu sesuai dengan kondisi yang melingkupi di sekitarnya. Pendekatan empirik yang dilakukan tidak lagi bersifat etik yang berakar dari keberadaan teori yang sudah berdiri sebelumnya. Pendekatan emic yang bersifat bottom up menjadi cara yang dipilih untuk dapat memahami perilaku individu sesuai dengan konteksnya. Dalam hal ini, kerangka maupun cara pandang dari individu tersebut menjadi poin penting. Selain menekankan pada pemahaman kontekstual, psikologi indigenous juga memiliki tujuan untuk mengarahkan pada upaya membangun sebuah prinsip yang umum dan universal dalam memahami perilaku manusia didasarkan pada pemahaman kontekstual yang sudah dibangun sebelumnya. Pemahaman tersebut oleh Hakim (2013) digambarkan dengan sebuah pernyataan yang menarik yaitu "dari lokal menuju global". 
Melalui pendekatan psikologi indigenous yang diusung dalam studi ini akan mengarahkan pada upaya peneliti untuk memahami nilai-nilai penting ketika dikaitkan dengan keberadaan etika serta pihak mana sajakah yang memiliki pengaruh terkait nilai tersebut. Studi ini diharapkan dapat menjadi dasar penelitian selanjutnya untuk memahami dinamika psikologi individu secara tepat tanpa adanya bias yang dikarenakan pemahaman berpikir secara etik.

\section{METODE}

\section{Partisipan}

Responden dalam penelitian ini adalah mahasiswa di Universitas Paramadina dengan total 132 mahasiswa (84 perempuan dan 48 laki-laki).

\section{Desain}

Penelitian ini menggunakan pendekatan kualitatif yang berupa kualitatif analisis isi. Penelitian kualitatif analisis isi, menurut Hsieh dan Shannon (2005), merupakan metode penelitian kualitatif yang mengarahkan peneliti untuk melihat makna dari data yang sifatnya tekstual (kuesioner terbuka) secara subjektif melalui proses klasifikasi koding yang sistematis.

\section{Prosedur}

Alat ukur dalam penelitian ini menggunakan kuesioner terbuka yang terdiri dari 2 pertanyaan, yaitu "nilai seperti apa yang paling ditekankan dalam konteks etika?" dan "siapa saja/pihak mana yang memberikan pengaruh penting dalam penguatan konsep moral tersebut?". Dalam penelitian ini pengambilan data dilakukan dengan menyebarkan kuesioner kepada mahasiswa di Universitas Paramadina. Responden diminta untuk mengisi kuesioner yang telah diberikan dan dari jawaban responden tersebut proses analisis data dilakukan untuk mendapatkan hasil penelitian.

\section{Teknik Analisis}

Teknik analisis data yang digunakan dalam penelitian ini adalah analisis konten induktif (Elo \& Kyngäs, 2008). Analisis konten induktif mengarahkan pada peneliti untuk membangun kesimpulan berdasarkan pada jawaban responden dibandingkan membuktikan suatu teori yang sudah ada. Tahapan analisis yang harus dilaksanakan yaitu: 
Pertama, open coding yang merupakan tahap awal berupa pemberian catatan-catatan tertentu oleh peneliti terkait jawaban pada responden. Catatan tersebut nantinya akan mengarahkan peneliti pada pengkategorian. Kedua, kategorisasi yang mengarahkan pada peneliti untuk melakukan pengelompokan jawaban responden sesuai dengan kategori-kategori yang sudah dibentuk sebelumnya berdasar kata kunci yang ditemukan. Ketiga, abstraksi yang merupakan tahap membuat kesimpulan berupa gambaran umum sebuah konsep berdasarkan pada kategori-kategori yang sudah diperoleh sebelumnya. Upaya untuk memperoleh hasil penelitian yang baik, dalam penelitian ini dilakukan proses intercoder agreement yang berupa melakukan pemeriksaan kembali hasil analisis data dan membuat kesepakatan bersama terkait tema yang diperoleh atas jawaban responden antar peneliti (Creswell, 2009).

ANALISIS DAN HASIL

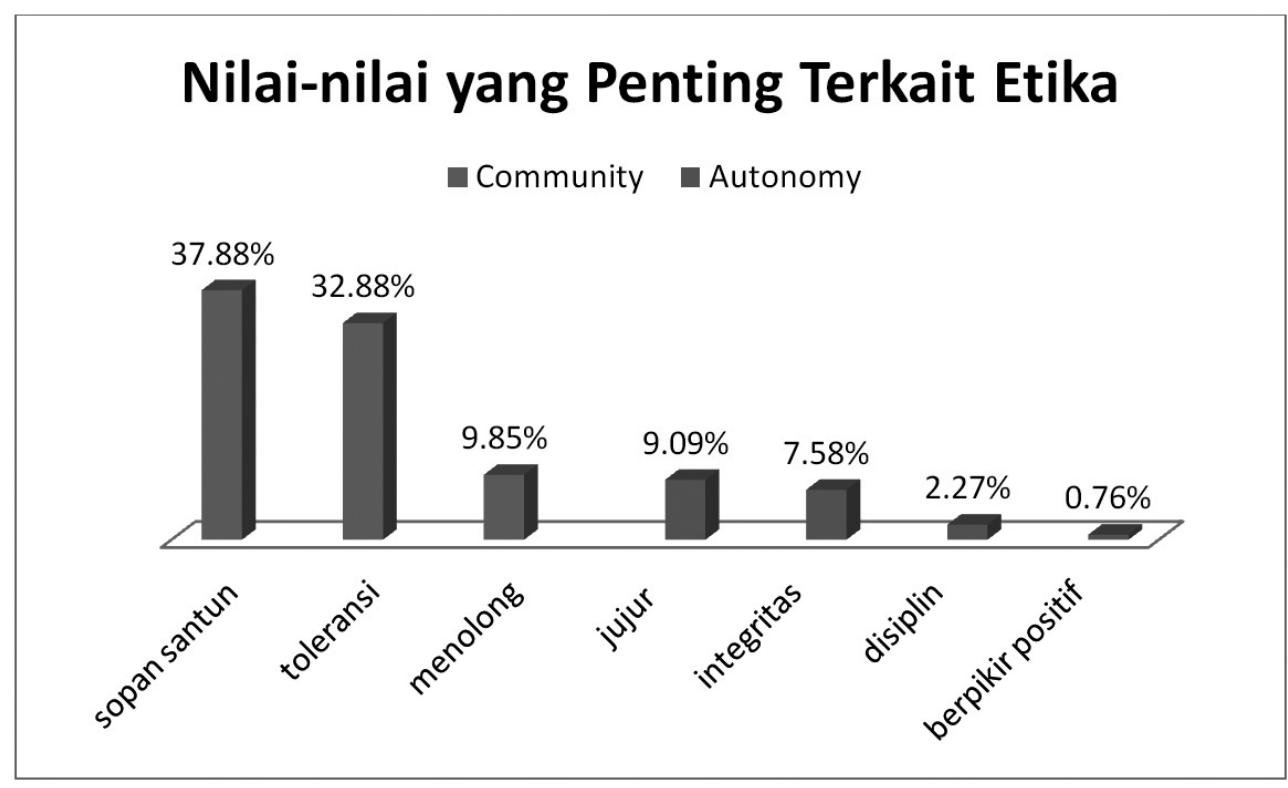

Diagram 1. Nilai-nilai yang Penting Terkait Etika

Berdasarkan pada gambar 1 dapat dilihat bahwa nilai-nilai yang dianggap penting terkait dengan konteks etika berdasarkan jumlah responden adalah sopan santun (37.88\%), toleransi (32.88\%), menolong (9.85\%), jujur (9.09\%), integritas (7.58\%), disiplin (2.27\%), dan berpikir positif (0.76\%). Lebih lanjut dapat dijelaskan bahwa untuk nilai-nilai yang terkait dengan etika yang berorientasi pada konteks community/komunal sekitar $80 \%$ yang berupa sopan santun, toleransi, dan menolong. Untuk nilai-nilai yang terkait dengan etika yang berorientasi pada konteks autonomy/individual sekitar 
20\% yang berupa jujur, integritas, disiplin, dan berpikir positif. Berdasarkan pada hasil tersebut dapat disimpulkan bahwa mayoritas keberadaan nilai-nilai yang erat kaitannya dengan konteks etik mengarahkan pada penghormatan dan pemenuhan kebutuhan orang lain yang diindikasikan berorientasi pada etika community.

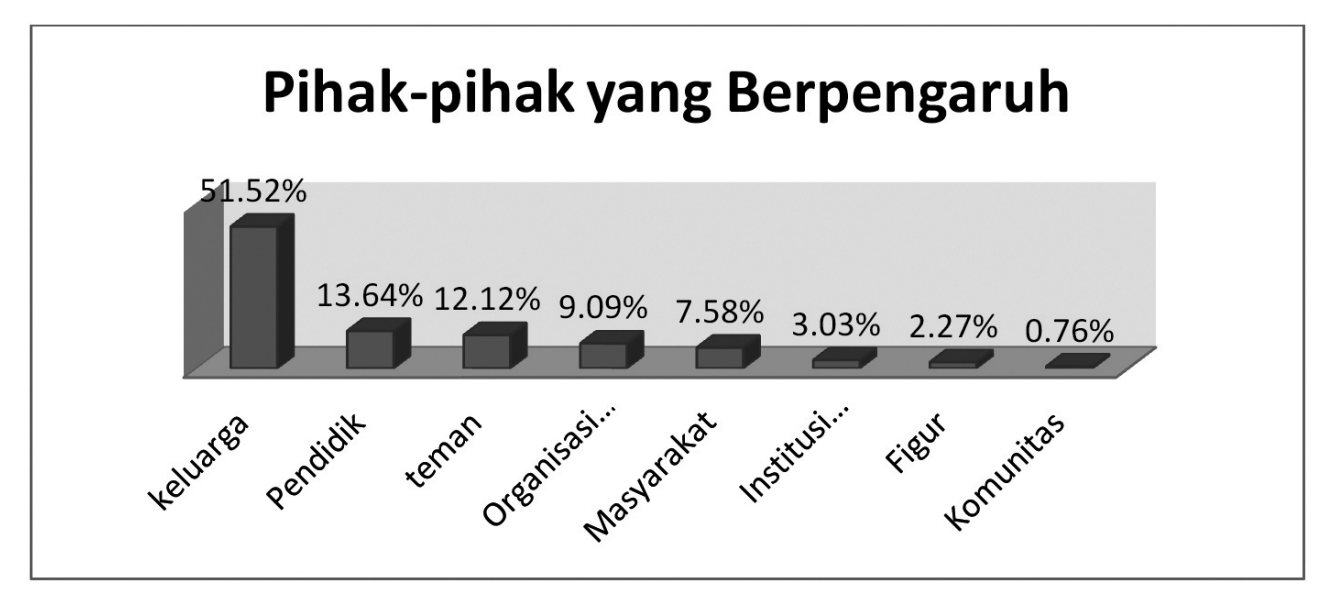

Diagram 2. Pihak-pihak yang Berpengaruh terhadap Munculnya Nilai

Berdasarkan pada hasil penelitian yang ada, diperoleh bahwa pihak-pihak yang berpengaruh pada munculnya nilai-nilai yang terkait dengan etika adalah keluarga (51.52\%), pendidik (13.64\%), teman (12.12\%), organisasi mahasiswa (9.09\%), masyarakat (7.58\%), institusi pendidikan (3.03\%), figur $(2.27 \%)$, dan komunitas $(0.76 \%)$. Berdasarkan pada hasil tersebut dapat disimpulkan bahwa keberadaan keluarga menjadi salah satu pihak yang mayoritas dianggap memiliki peran penting dalam proses pemahaman etika tersebut.

\section{DISKUSI}

Etika pada dasarnya mengarahkan pada keberadaan satu aturan yang erat kaitannya dengan keberadaan moral yang tidak dapat terlepas dari keberadaan budaya yang berada di sekitarnya. Pembahasan mengenai etika dan kebudayaan dalam kajian psikologi tidak jarang diarahkan pada konteks individualisme-kolektivisme yang mengarahkan pada keberadaan etika yang berorientasi autonomy, community, dan divinity. Berbicara mengenai masyarakat non-Barat yang seringkali diasosiasikan dengan masyarakat Asia, keberadaan konteks etika diorientasikan dalam bentuk community (Morelli 
\& Rothbaum, 2007). Penekanan etika yang berbasis community ini mengarahkan pada kelekatan hubungan yang mengarahkan pada bentuk harmoni, pelaksanaan tugas, menghormati, serta kepatuhan. Hal tersebut sejalan dengan hasil penelitian yang sudah dilakukan dengan responden para mahasiswa. Berdasarkan pada hasil penelitian dapat diketahui bahwa nilai-nilai yang penting terkait dengan etika dalam hal ini sopan santun (37.88\%), toleransi (32.58\%), dan menolong (9.85\%). Mayoritas jawaban responden yang menggambarkan nilai penting terkait etika sangat erat dengan gambaran menghormati individu lain dan mengarahkan pada keberadaan harmoni (Miller \& Rothbaum, 2007), serta pemenuhan kebutuhan orang lain (Shweder dkk., dalam Miller, 2007).

Nilai sopan santun, toleransi, dan menolong yang erat dengan gambaran menghormati individu lain, mengarahkan pada harmoni serta pemenuhan kebutuhan orang lain secara lebih detail dapat terlihat dari beberapa jawaban para responden yang berupa:

“budaya tata krama sopan santun.” (R7)

"rendah hati, mampu bersikap baik terhadap orang, mudah berinteraksi dengan orang lain." (R22)

"menghormati satu sama lain." (R69)

"konsep-konsep baik dan positif yang dapat memberikan manfaat tidak bagi perorang tetapi bagi banyak orang." (R.72)

"sopan santun, saling menghargai, toleransi." (R86)

"bersikap kepada orang lain menyesuaikan adat yang berlaku." (R110)

"tahu bersikap dalam suasana tertentu, dapat bekerjasama dengan orang lain dan mau mendengarkan pendapat orang lain tidak egois." (R122)

Keberadaan nilai-nilai terkait etika bagi responden seperti halnya yang sudah dijelaskan di atas juga tidak dapat dilepaskan dari keberadaan pihak yang memberikan pemahaman serta pembelajaran nilai tersebut. Berdasarkan pada jawaban responden, peringkat pertama pihak yang memberikan pengaruh terkait nilai etika tersebut adalah keluarga dengan persentase sebesar $51.52 \%$ dan sisanya 48.48\% di luar lingkup keluarga (pendidik, teman, organisasi mahasiswa, masyarakat, institusi pendidikan, figur dan komunitas). Proses pembelajaran suatu nilai maupun aturan yang terdapat di masyarakat dan budaya dalam hal ini tidak terlepas dari proses sosialisasi dan enkulturasi (Matsumoto \& Juang, 2003). Dijelaskan lebih lanjut bahwa keberadaan orangtua merupakan agen yang paling pertama dan utama dalam proses pembelajaran tersebut.

Dalam penjelasan yang lain Friedman (dalam Quyen \& Zaharim, 2012) juga menjelaskan bahwa pembelajaran nilai-nilai yang erat kaitannya dengan moral oleh individu pertama kali tidak terlepas dari orangtua atau keluarga. Keberadaan orangtua sebagai agen sosialisasi dan enkulturasi 
bagi individu dalam hal ini berperan dalam proses transmisi budaya yang bersifat vertikal (Berry \& Cavalli-Sforza, dalam Berry, Poortinga, Segall, \& Dasen, 2002). Proses pembelajaran mengenai satu nilai maupun aturan dalam satu masyarakat atau budaya yang selanjutnya setelah orangtua dalam perkembangannya dipengaruhi oleh keberadaan lingkungan sekitar (teman, masyarakat, keluarga luas, dan lain-lain) dalam hal ini masuk dalam transmisi nilai yang bersifat oblique dan horizontal (Berry \& Cavalli-Sforza, dalam Berry dkk., 2002)

Penelitian ini pada dasarnya memiliki keterbatasan yang nantinya dapat disempurnakan untuk mendapatkan hasil yang lebih baik ke depan. Beberapa batasan yang ada dalam penelitian ini terkait dengan sampel yang masih bersifat terbatas dan metode pengambilan data yang perlu dikembangkan. Khususnya terkait dengan metode pengambilan data penelitian selanjutnya dapat menambahkan metode Focus Group Discussion (FGD) maupun wawancara mendalam untuk dapat memperoleh gambaran dinamika yang lebih jelas terkait dengan motif dalam berperilaku terkait dengan nilai-nilai tersebut. Hal ini tidak terlepas dari pemaparan yang dijelaskan oleh Triandis dan Suh (2002) bahwa orientasi nilai untuk menolong dapat saja mengarahkan pada konteks etika autonomy. Kondisi tersebut tidak terlepas dari motif individu dalam menolong apakah memang sebagai bentuk pilihan bebas dalam diri yang mengarahkan pada konteks autonomy atau tuntutan pemenuhan sosial yang mengarahkan pada konteks community.

\section{SIMPULAN DAN SARAN}

\section{Simpulan}

Berdasarkan pada hasil penelitian dapat disimpulkan bahwa nilai-nilai yang penting bagi para responden terkait dengan etika mengarah pada bentuk etika yang berorientasi community. Hal ini terlihat dari jawaban para responden yang mayoritas sekitar $80 \%$ mengarahkan pada nilai-nilai sopan santun, toleransi, dan menolong. Para responden menekankan pada etika yang mengarahkan pada kelekatan hubungan dengan mengarahkan pada harmoni, pelaksanaan tugas, menghormati, serta kepatuhan. Keberadaan nilai-nilai tersebut dalam prosesnya sangat dipengaruhi dengan keberadaan keluarga/ orangtua yang mencapai $51.52 \%$ dan sisanya $48.48 \%$ mengarahkan pada pendidik, teman, organisasi mahasiswa, masyarakat, institusi pendidikan, figur, dan komunitas. 


\section{Saran Teoretis}

Perlu adanya pengembangan penelitian lebih lanjut terkait dengan hasil yang diperoleh. Pengembangan penelitian ini dapat dilaksanakan dengan menambah metode pengambilan data, yaitu melalui Focus Group Discussion atau wawancara. Hal ini sebagai upaya melihat gambaran yang lebih komprehensif. Hal ini tidak terlepas dari gambaran mengenai nilai-nilai penting yang terkait etika dalam penelitian ini masih bersifat indikasi yang mengarahkan pada konteks etika yang berorientasi community. Indikator awal tersebut dapat saja berubah orientasi etika ketika dilakukan penelitian yang lebih mendalam, salah satunya terkait dengan motif dalam melakukan perilaku yang didasarkan pada nilai-nilai tersebut.

Perlu adanya pengembangan penelitian yang lebih luas secara sampel penelitian sehingga dapat diperoleh gambaran yang lebih menyeluruh terkait dengan konteks etika pada masyarakat Indonesia.

\section{Saran Praktis}

Perlu adanya penguatan nilai-nilai etika yang berorientasi community melalui pendidikan etika secara praktis baik di lingkungan keluarga, dunia pendidikan, maupun masyarakat. Hal ini tidak terlepas dari kondisi sosial saat ini yang rentan terjadi benturan sosial antar kelompok yang pada dasarnya bertentangan dengan nilai etika yang diyakini.

\section{REFERENSI}

Berry, J. W., Poortinga Y. H., Segall, M. H., \& Dasen, P. R. (2002). Cross-cultural psychology: Research and applications (2nd ed.). Cambridge, UK: Cambridge University Press.

Chippendale, P. (2001). On values, ethics, morals and principles. Ditemu kembali dari http://econ. au.dk/fileadmin/Economics_Business/Currently/Events/PhDFinance/Kauttu_On_Values_ Ethics_Morals___Principles_-_Chippendale.pdf

Creswell, J. W. (2009). Research design: Qualitative, quantitative, and mixed methods approaches (3rd ed.). California: Sage Publications.

Elo, S. \& Kyngäs, H. 2008. The qualitative content analysis process. Journal of Advanced Nursing, $62(1), 107-115$. 
Etika. (n.d.). Kamus Besar Bahasa Indonesia. Ditemu kembali dari http://kbbi.web.id/etika

Hakim, M. A. (2013). Dari lokal menuju global: Berfikir kontekstual, indigenous psychology, dan masa depan psikologi Indonesia di arena global (Karya kuliah umum tidak dipublikasikan). Universitas Paramadina, Indonesia.

Hsieh, H.-F., \& Shannon, S. E. (2005). Three approaches to qualitative content analysis. Qualitative Health Research, 15(9), 1277-1288.

Kara, M. A. (2007). Applicability of the principle of respect for autonomy: The perspective of Turkey. Journal of Medical Ethics, 33, 627-630.

Kim, U., \& Berry, J. W. (1993). Introduction. Dalam U. Kim \& J. W. Berry (Eds), Indigenous psychologies: Research and experience in cultural context (pp. 1-29). Newbury Park, CA: Sage.

Kim, U., Yang, K.-S., \& Hwang, K.-K. (2010). Indigenous and cultural psychology (H. P. Soetjipto \& S. M. Soetjipto, Trans.). Yogyakarta, Indonesia: Pustaka Pelajar.

Matsumoto, D., \& Juang, L. (2003). Culture and psychology (3rd ed.) New York, NY: Wadsworth.

Miller, J. G. (2007). Cultural psychology of moral. Dalam S. Kitayama \& D. Cohen (Eds.), Handbook of cultural psychology (pp. 477-499). New York, NY: The Guilford Press.

Morelli, G. A., \& Rothbaum, F. (2007). Situating the child in context: Attachment relationships and self-regulation in different cultures. Dalam S. Kitayama \& D. Cohen (Eds.), Handbook of cultural psychology (pp. 500-527). New York, NY: The Guilford Press.

Quyen, L. T. D., \& Zaharim, N. M. (2012). The relationship between friendship characteristics, ethnic identity and value systems of youths from ethnic minority groups in Vietnam: A conceptual framework for research. International Journal of Humanities and Social Science, 2(23), 133-139.

Ryan, T. G., \& Bisson, J. (2011). Can ethic be taught? International Journal of Business and Social Science, 2(12), 44-52.

Shweder, R. A. (2000). The psychology of practice and the practice of the three psychologies. Asian Journal of Social Psychology, 3, 207-222.

Triandis, H. C., \& Suh, E. M. (2002). Cultural influences on personality. Annual Reviews of Psychology, $53,153-160$.

Zegwaard, K., \& Campbell, M. P. (2011). Ethic and values: The need for student awareness of workplace values systems. Ditemu kembali dari http://www.waceinc.org/philly2011/conference_ proceedings/Refereed\%20Papers/New\%20Zealand/KARSTE 1.PDF 